\title{
Evidence of XX/XY Sex Chromosome Mosaicism in a Child with True Hermaphroditism
}

\author{
P. H. FITZGERALD, L. A. BREHAUT, F. T. SHANNON, and H. B. ANGUS \\ From the Cytogenetics Unit, ${ }^{*}$ and Departments of Paediatrics and Pathology, Christchurch Hospital, \\ Christchurch, New Zealand
}

True hermaphrodites possess both ovarian and testicular tissues which may be present in separate gonads or combined in an ovotestis. External and internal genitalia are ambiguous and variable, though a prominent penial structure is usual.

Chromosome examination of true hermaphroditism has revealed an $\mathrm{XX}$ sex chromosome complement in the majority of cases, but the XY complement and different mosaic constitutions have also been described (see reviews of Miller, 1964; Dewhurst et al., 1965; Turpin and Lejeune, 1965; Yunis, 1965; Mittwoch, 1967). The most interesting mosaic constitution is $\mathrm{XX} / \mathrm{XY}$ which has been reported in four true hermaphrodites (Gartler, Waxman, and Giblett, 1962; Grouchy et al., 1964; Overzier, 1964; Brøgger and Aagenaes, 1965). We describe a further true hermaphrodite who has both XX and XY cells.

\section{Case Report}

The propositus is the first-born child of healthy, nonrelated parents, and has one younger normal female sib. The child was delivered normally at $\mathbf{4 2}$ weeks' gestation after an uncomplicated pregnancy, birthweight $3571 \mathrm{~g}$. He had a conspicuous hypospadias but otherwise appeared normal. Subsequently, his motor development and his intelligence have proved to be normal.

Examination at the age of 8 weeks revealed gross hypospadias with a urethral opening into the perineum, a bifid and rugose scrotum, and a testis palpable in the left inguinal canal. At $2 \frac{1}{2}$ years an intravenous pyelogram was normal, and at 3 years and 5 months a micturating cystourethrogram showed no abnormality.

An investigatory laparotomy, performed when the child was aged 4 years and 4 months, revealed an apparent testis with tunica vaginalis on the left side, and an ovary with a normal fimbriated Fallopian tube on the right side. There was a rudimentary uterus and vagina in the midline. Biopsies were taken of both gonads. Microscopical examination of the right gonadal biopsy

Received 15 December 1969

* Supported by the Canterbury and Westland Division of the Cancer Society of New Zealand. showed normal ovarian tissue with primordial and Graafian follicles. The left gonad showed normal testicular tissue, but had a single ovarian primordial follicle at one edge, indicating that the gonad was an ovotestis.

The gonads and other reproductive structures were examined in detail following their removal at a subsequent laparotomy. The uterus with cervix was $3.5 \mathrm{~cm}$. long and of normal appearance. A normal Fallopian tube, $3 \mathrm{~cm}$. long with fimbriated end, extended from the right cornu to an oval-shaped ovary measuring $2 \times 0.8 \times$ $0.4 \mathrm{~cm}$. Several small cysts were visible beneath the capsule. A cord $7 \mathrm{~cm}$. long extended from the left cornu, and a gonad measuring $1.5 \times 0.8 \times 0.8 \mathrm{~cm}$. was partly attached to its distal end. The distal $3 \mathrm{~cm}$. of cord and gonad was encased in a continuous layer of fibrous tissue covered by serous membrane, resembling a testis and spermatic cord with visceral tunica vaginalis. Histologically the uterus and cervix showed a normal infantile appearance with prominent remnants of mesonephric ducts in the outer myometrium. The right tube had the typical fimbriated structure of a Fallopian tube distally, and the left tube was simple with muscular coats and central lumen lined by cuboidal epithelium. Both gonads were sectioned completely for microscopical examination. The right gonad showed normal ovarian stroma with primordial follicles, scattered Graafian follicles, and follicular cysts. Vestigial remnants of Wolffian body were present in the parovarian fibrous tissue. The left gonad was an ovotestis, about twothirds comprising infantile testicular tissue with an epididymis-like collection of ducts, and the remaining one-third showing ovarian-type stroma containing primordial and atretic follicles (Fig. 1).

Sex chromatin. Smears of buccal mucosa taken from the patient at the age of 8 weeks, and repeated at the ages of 3 years and 4 years, showed between 2 and $3 \%$ sex chromatin positive cells. These values are considerably lower than the normal female range.

Blood granulocytes, examined when the patient was 3 years old and again at 4 years, were approximately $1 \%$ sex chromatin positive. This is within the lower portion of the normal female range.

Chromosome examination. Blood leucocytes were cultured for 3 days with phytohaemagglutinin according 


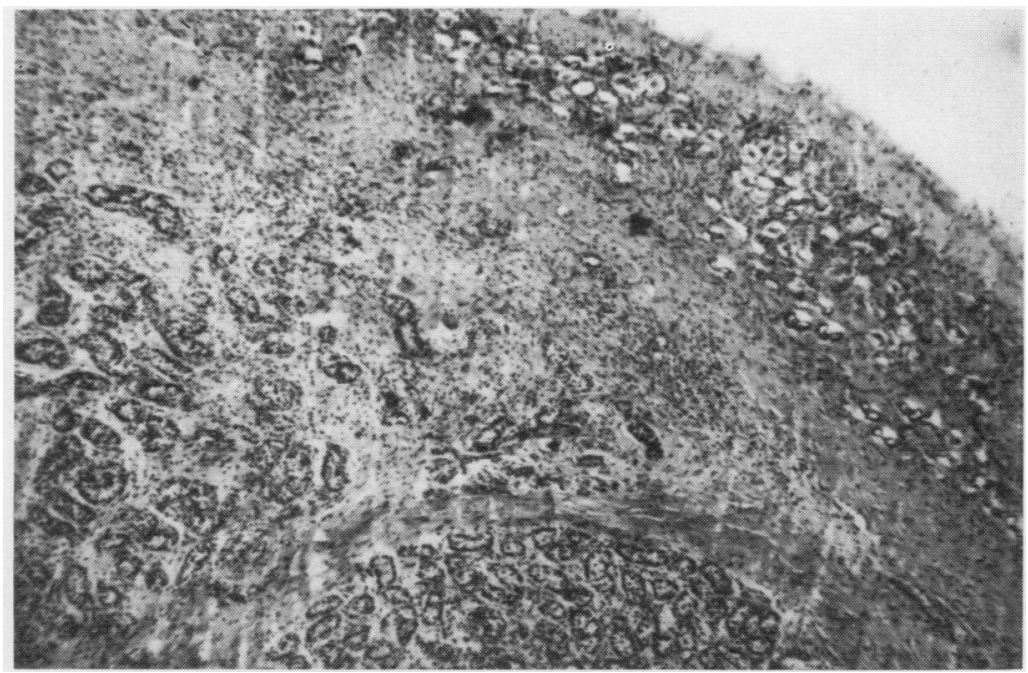

FIG. 1. Left ovotestis, showing testicular seminiferous tubules, and ovarian primordial follicles peripherally. $(\times 80$.)

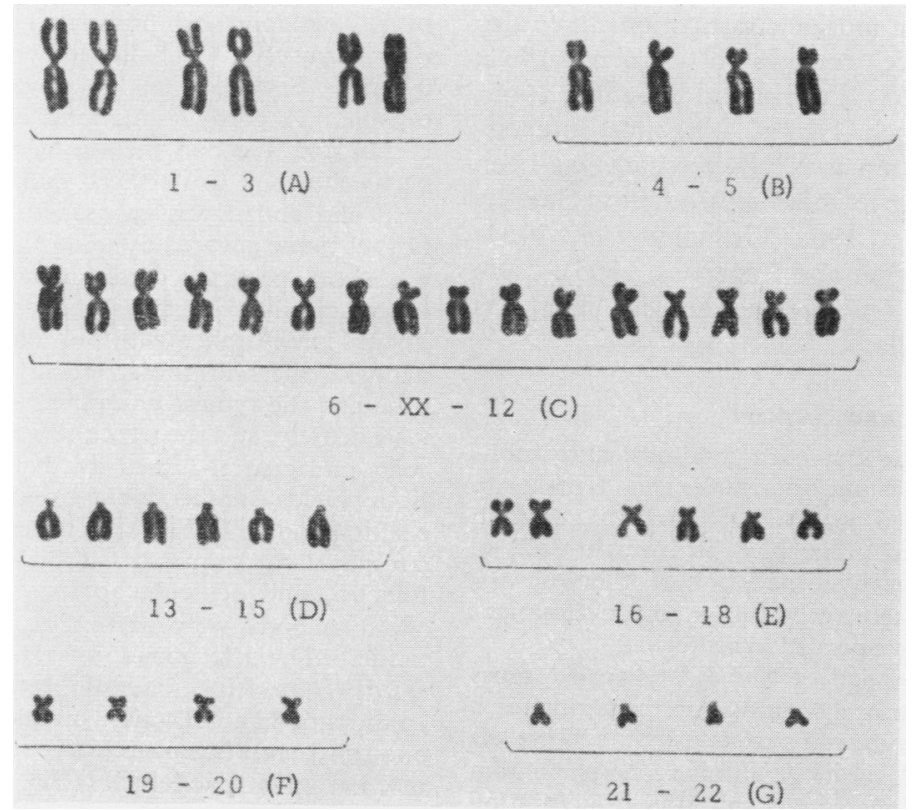

FIG. 2. Cultured lymphocyte with 46 chromosomes and a female sex chromosome complement.

to the method of Moorhead et al. (1960). In 4 separate examinations, when the child was $2 \frac{1}{2}$ years, 3 years and 10 months, 4 years and 4 months, and $6 \frac{1}{2}$ years of age, mitoses showed a normal diploid count of 46 chromosomes, and all had a female chromosome complement (Table I, Fig. 2). ${ }^{3} \mathrm{H}$-thymidine autoradiographs prepared from the last blood culture showed a late-labelling $\mathrm{C}$ group chromosome, presumably $\mathrm{X}$, in $86 \%$ of suitably labelled metaphases (Fig. $3 \mathrm{a}$ and $\mathrm{b}$ ).
Skin from the left arm of the patient at 4 years and 4 months was cultured by the method of Harnden and Brunton (1965). Dividing fibroblasts had a normal diploid count, but both female and male cells were present (Table I, Fig. 4).

A skin sample from the lower abdomen and tissues from the left and right gonads were lost in culture. Cultures of further skin samples taken from the left and right forearms when the patient was 5 years and 4 
TABLE I

CYTOGENETIC FINDINGS IN XX/XY MOSAICISM

\begin{tabular}{|c|c|c|c|c|c|}
\hline \multirow{2}{*}{$\begin{array}{l}\text { Case } \\
\text { No. }\end{array}$} & \multirow{2}{*}{ Reference } & \multirow{2}{*}{ Diagnosis } & \multirow{2}{*}{$\begin{array}{l}\text { Tissue } \\
\text { Examined }\end{array}$} & \multicolumn{2}{|c|}{ No. of Cells } \\
\hline & & & & $\mathbf{x X}$ & $\mathbf{X Y}$ \\
\hline 1 & Present case & $\begin{array}{l}\text { True hermaphrodite, raised as } \\
\text { male: left ovotestis, right ovary }\end{array}$ & $\begin{array}{cc}\text { Blood } 1 \\
\text { " } & 2 \\
y & 3 \\
\text { ?g } & 4 \\
\text { Skin lt. arm 1 } & \\
\text {, lt. arm 2 } & \text { rt. arm 1 }\end{array}$ & $\begin{array}{r}21 \\
58 \\
23 \\
100 \\
25 \\
93 \\
91\end{array}$ & $\begin{array}{l}0 \\
0 \\
0 \\
0 \\
4 \\
0 \\
1\end{array}$ \\
\hline 2 & Brøgger and Aagenaes (1965) & $\begin{array}{l}\text { True hermaphrodite, raised as } \\
\text { male: left ovary, right testis }\end{array}$ & $\begin{array}{l}\text { Blood } \\
\text { Bone-marrow } \\
\text { Skin } \\
\text { Rt. gonad 1 } \\
\text { Rt. gonad } 2\end{array}$ & $\begin{array}{l}20 \\
17 \\
10 \\
25 \\
32\end{array}$ & $\begin{array}{r}0 \\
0 \\
0 \\
0 \\
18\end{array}$ \\
\hline 3 & $\begin{array}{l}\text { Grouchy et al. (1964) } \\
\text { Josso et al. (1965) }\end{array}$ & $\begin{array}{l}\text { True hermaphrodite, raised as } \\
\text { male: left ovary, right ovotestis }\end{array}$ & $\begin{array}{cc}\text { Blood } & 1 \\
\text { Skin } & 2 \\
\text {, } & 2\end{array}$ & $\begin{array}{r}14 \\
9 \\
17 \\
13\end{array}$ & $\begin{array}{l}9 \\
5 \\
8 \\
6\end{array}$ \\
\hline 4 & $\begin{array}{l}\text { Gartler et al. (1962) } \\
\text { Waxman et al. (1962) } \\
\text { Giblett, Gartler, and Waxman (1963) }\end{array}$ & $\begin{array}{l}\text { True hermaphrodite, raised as } \\
\text { female: left ovary, right ovotestis }\end{array}$ & $\begin{array}{l}\text { Blood } \\
\text { Skin 1 } \\
\text { "y 2 } \\
\text { Ovary } \\
\text { Ovotestis } 1 \\
\text { Clitoris }\end{array}$ & $\begin{array}{r}7 \\
3 \\
8 \\
10 \\
9 \\
2 \\
4\end{array}$ & $\begin{array}{r}6 \\
10 \\
1 \\
0 \\
2 \\
12 \\
7\end{array}$ \\
\hline 5 & Overzier (1964) & $\begin{array}{l}\text { True hermaphrodite, raised as } \\
\text { female: ovotestis only }\end{array}$ & $\begin{array}{l}\text { Blood } \\
\text { Skin } \\
\text { lt. gonad }\end{array}$ & $\begin{array}{r}2 \\
3 \\
42\end{array}$ & $\begin{array}{r}50 \\
49 \\
110\end{array}$ \\
\hline 6 & $\begin{array}{l}\text { Beattie et al. (1964) } \\
\text { Zuelzer et al. (1964) }\end{array}$ & $\begin{array}{l}\text { Male, ?hermaphroditism: left and } \\
\text { right testis }\end{array}$ & $\begin{array}{l}\text { Blood } 1 \\
\text { Skin } 1 \\
: 2\end{array}$ & $\begin{array}{r}11 \\
4 \\
0 \\
9\end{array}$ & $\begin{array}{r}139 \\
96 \\
91 \\
72\end{array}$ \\
\hline 7 & Bain and Scott (1965) & Female, mixed gonadal dysgenesis & $\begin{array}{c}\text { Blood } 1 \\
, 2\end{array}$ & $\begin{array}{r}7 \\
12\end{array}$ & $\begin{array}{l}43 \\
24\end{array}$ \\
\hline 8 & Forteza et al. (1963) & Female, gonadal dysgenesis & Blood & 14 & 13 \\
\hline
\end{tabular}

months showed only $1 \mathrm{XY}$ cell in 185 mitotic cells, the remainder being $\mathrm{XX}$ (Table $\mathrm{I}$ ). All skin cells were examined after about 21 days in culture.

Blood group data. Blood group data of the family including the patient are presented in Table II. The patient's blood groups were consistent with normal inheritance from his parents. There was no evidence of a mixed red cell population suggesting a double genetic contribution from either parent.

Further management. Psychiatric assessment of parental attitudes and of the sexual orientation of the child indicated that the male sex pattern was firmly established, and that there was potential psychological hazard in attempting to realign this in the female direction.

Before irreversible surgical procedures were undertaken, end-organ response to hormonal stimuli was tested by the local application of $0.2 \%$ testosterone ointment to the genital region. A 6-week treatment produced quite definite enlargement of the phallus and early growth of pubic hair.

At the age of 4 years and 10 months, the ovo-testis and ovary were removed together with the uterus and upper portion of vagina, and planned plastic reconstruction of urethra and phallus is now proceeding. The childs' social orientation both at home and at school follows a normal male pattern.

\section{Discussion}

The presence of both ovarian and testicular tissue indicates that the patient is a true hermaphrodite, and chromosome examination of skin cells suggests $\mathrm{XX} / \mathrm{XY}$ mosaicism. Such mosaicism is consistent with the abnormally low chromatin count

TABLE II

FAMILY BLOOD GROUP DATA

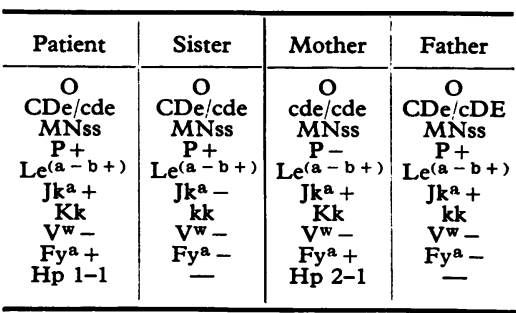




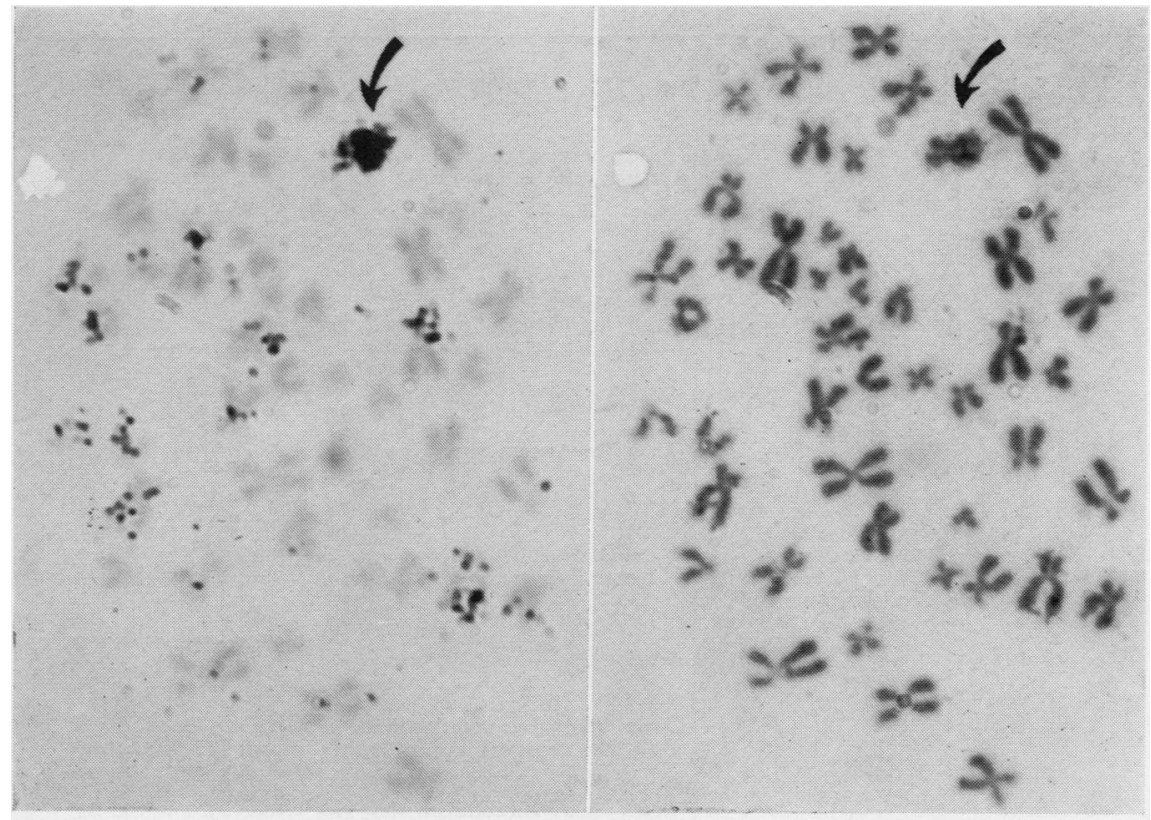

(a)

(b)

FIG. 3. (a) Autoradiograph of the chromosomes of a cultured lymphocyte labelled with ${ }^{3} H$-thymidine. Note the heavily labelled $X$ chromosome (arrow). (b) The same cell after the silver grains have been removed by potassium ferricyanide.

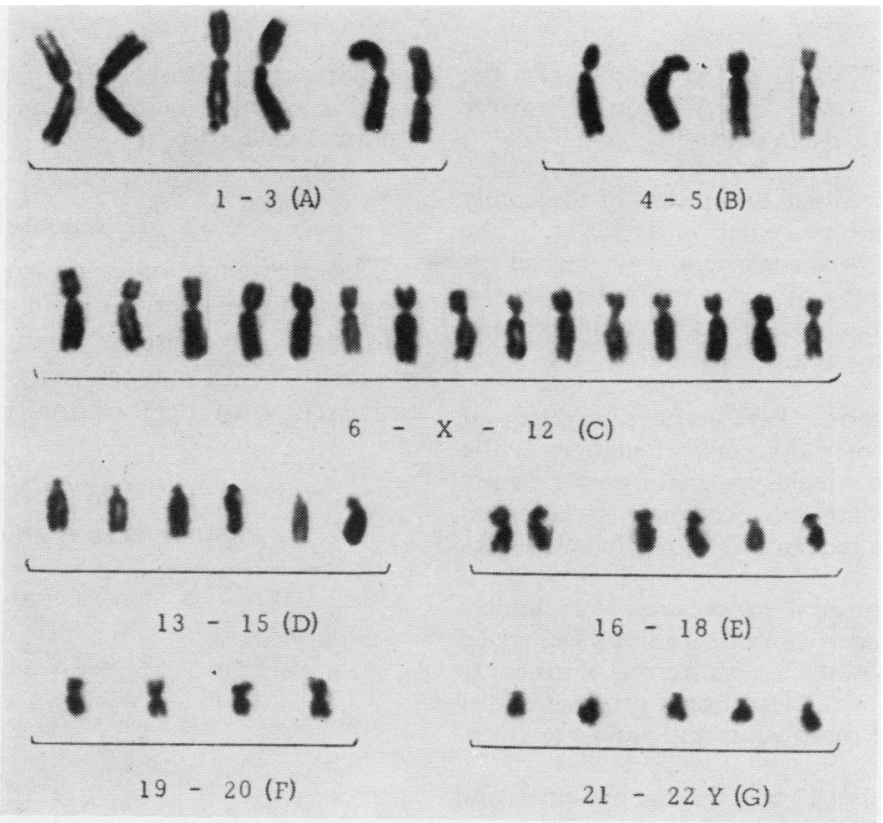

Fig. 4. Cultured fibroblast from a skin biopsy with 46 chromosomes and a male sex chromosome complement. 
in buccal mucosal cells. The presence of only one cell type, $\mathrm{XX}$, in blood cultures and the normal sex chromatin positivity of granulocytes indicate that blood-forming elements were not involved in the mosaicism.

The low proportion of male cells, particularly in the second skin culture, demands comment. There is always a possibility that fibroblast cultures, which are continued for several weeks with frequent medium changes, have been contaminated by foreign cells. Such cells should be few in number, however, and contamination is not a likely explanation of the male cells in the first skin culture. No other fibroblast cultures were present in the laboratory at the times cells from the patient were cultured.

The absence of male cells in blood and their low frequency in skin should instead be considered in relation to the usual finding of solely XX cells in true hermaphroditism, a condition that appears to contradict the general finding in human and mammalian cytogenetics of the need of a $Y$ chromosome for the development of testicular tissue. One suggested explanation of the anomaly is that all true hermaphrodites with an apparent XX sex chromosome constitution are undetected mosaics in which one of the cell lines has a $\mathrm{Y}$ chromosome. In several cases relatively few cells, often from a single sample, have been examined and mosaicism may well have been missed. A second possibility is that a mixed cell population does not occur in all tissues of a mosaic individual, and may even be confined to the gonadal areas, as appeared to be the case in the $\mathrm{XX} / \mathrm{XY}$ mosaic of Brøgger and Aagenaes (1965) in which male cells were not found in lymphocytes, bone-marrow, skin, and cultured cells from a testicular biopsy, but only in cultured cells from a second biopsy of the same gonad. A third consideration is differential change in the frequencies of cell lines during fetal and infant growth periods, and it has been suggested that some hermaphrodites with an XX sex chromosome complement originated as $\mathrm{XX} / \mathrm{XY}$ mosaics in which $\mathrm{XX}$ cells gained ascendancy (Mittwoch, 1967). Cell line selection has not been seen in these mosaics, but there is good evidence for selection of particular cell lines in other mosaics, particularly during infant growth (Hecht et al., 1966; Ford, 1967; Taylor, 1968; Porter et al., 1969). It is possible that the present patient represents an $\mathrm{XX} / \mathrm{XY}$ mosaic in which $\mathrm{XX}$ cells gained ascendancy, completely in blood and incompletely in skin. The continuation of selection during infant growth is also a possible explanation of the reduced number of male cells in the second skin cultures, though differential cell selection during the three-week period of in vitro culture must also be considered.

A minority of true hermaphrodites are known to be $\mathrm{XX} / \mathrm{XY}$ sex chromosome mosaics. The four patients described previously (Waxman, Gartler, and Kelley, 1962; Overzier, 1964; Josso et al., 1965; Brøgger and Aagenaes, 1965), and the present patient are typical true hermaphrodites with ambiguous external genitalia featuring a prominent clitoris/phallus and different degrees of fusion of the scroto-labial folds. In no case did the phallus contain the urethra, which instead opened into the perineum or vagina. All five patients had a vagina and uterus, usually with Fallopian tubes. Three patients had an ovary on one side and an ovotestis on the other, one patient (Brogger and Aagenaes, 1965) had a left ovary and a right testis, though the presence of an ovotestis cannot be excluded because biopsies only were examined, and the remaining patient (Overzier, 1964) had a single mixed gonad which was predominantly testis.

The $\mathrm{XX} / \mathrm{XY}$ mosaic chromosome complement does not always produce the phenotype of true hermaphroditism, and has been reported in a chromatin-negative woman with gonadal dysgenesis (Forteza et al., 1963), in a woman with mixed gonadal dysgenesis (Bain and Scott, 1965), and in an apparently normal adult man with only equivocal evidence of hermaphroditism, who was detected from ambiguous blood group findings (Beattie et al., 1964; Zuelzer, Beattie, and Reisman, 1964). Such wide phenotypic variation of the $\mathrm{XX} / \mathrm{XY}$ complement probably results in part from the presence of different proportions of $\mathrm{XX}$ and $\mathrm{XY}$ cells in the gonadal ridge at the time of gonad formation. The proportions of cells found at cytogenetic examination probably bear little relation to these original proportions, but nevertheless suggest some interesting differences which may not be merely fortuitous. The first three patients (Table I) had a predominance of XX cells in all tissues examined, and were closely similar hermaphrodites raised as males. Cases 5, 6, and 7 (Table I) on the other hand had a predominance of $\mathrm{XY}$ cells in several tissues, and clinically were most diverse, encompassing true hermaphroditism in a patient raised as a female, an apparently normal male, and mixed gonadal dysgenesis.

Possible modes of origin of $\mathrm{XX} / \mathrm{XY}$ mosaicism have been reviewed by Bain and Scott (1965), and there is positive evidence for some of them. Blood group studies on one patient (Waxman et al., 1962; Gartler et al., 1962) indicated a mixed red cell population with representation of both paternal alleles of some blood loci. Because there was no evidence of 
a double maternal contribution, it was suggested that two egg nuclei, the result of a mitotic division of a haploid ovum nucleus, had been fertilized by two spermatozoa. On the other hand, Zuelzer et al. (1964) found that both parents had made a two allelic contribution to the blood groups of their patient, and considered that $\mathrm{XX} / \mathrm{XY}$ mosaicism had resulted either from the fusion of two independent fertilized ova, or from the dispermy of a binucleate ovum which had retained a nucleus normally destined to become a polar body. Grouchy et al. (1964), Overzier (1964), and Bain and Scott (1965) considered that the mosaicism of their patients likewise arose from double fertilization though no data directly supported this view. The same situation exists with the present patient. Double fertilization is the most probable explanation of $\mathrm{XX} / \mathrm{XY}$ mosaicism, but the blood group and serum haptoglobin data gave no indication of this. However, the parental genotypes offered limited scope to detect double genetic contributions, and, in any case, it is possible from the cytogenetic data that the blood forming tissues were not involved in the mosaicism.

\section{Summary}

An apparently male child with obvious hypospadias was found at laparotomy to have a rudimentary uterus and vagina. The right gonad was an ovary and the left gonad an ovotestis. The sex chromosome complement in cultured leucocytes was consistently female, but cultured skin cells showed female and some male cells. It is suggested that the child is an $\mathrm{XX} / \mathrm{XY}$ mosaic in which $\mathrm{XX}$ cells gained ascendancy, completely in blood and incompletely in skin, during the fetal and infant growth periods.

We are grateful to Mr. P. E. Crossen and Mrs. Alison Pickering for cytogenetic studies, to Mr. W. L. F. Utley for the laparotomy reports, to Dr. J. R. Dobson for psychiatric assessment of the patient, and to $\mathrm{Mr}$. $\mathrm{K}$. McLoughlin for blood grouping.

\section{REFERENCES}

Bain, A. D., and Scott, J. S. (1965). Mixed gonadal dysgenesis with $\mathrm{XX} / \mathrm{XY}$ mosaicism. The evidence for the occurrence of fertilisation by two spermatozoa in man. Lancet, 1, 1035-1039.
Beattie, K. M., Zuelzer, W. W., McGuire, D. A., and Cohen, F. (1964). Blood group chimerism as a clue to generalized tissue mosaicism. Transfusion (Philadelphia), 4, 77-86.

Brøgger, A., and Aagenaes, O. (1965). The human Y chromosome and the etiology of true hermaphroditism. With the report of a case with $\mathrm{XX} / \mathrm{XY}$ sex chromosome mosaicism. Hereditas Genetiskt Arkiv, 53, 231-246.

Dewhurst, C. J., Warrack, A. J. N., Blank, C. E., Bishop, A. M., and Heslop, W. B. (1965). Chromosome mosaicism in a hermaphrodite. Fournal of Medical Genetics, 2, 246-250.

Ford, C. E. (1967). Discussion. In Mongolism. (Ciba Foundation Study Group No. 25), pp. 71-72. Ed. by G. E. W. Wolstenholme and R. Porter. J. and A. Churchill, London.

Forteza, G., Bonilla, F., Báguena, R., Monmeneu, S., Galbis, M., and Zaragozá, V. (1963). Un caso de mosaicismo XX/XY, cromatinnegativo, con disgenesia gonadal y sexo fenotípico femenino. Revista Clínica Española, 88, 394-398.

Gartler, S. M., Waxman, S. H., and Giblett, E. (1962). An XX/XY human hermaphrodite resulting from double fertilization. Proceedings of the National Academy of Sciences of the United States of America, 48, 332-335.

Giblett, E. R., Gartler, S. M., and Waxman, S. H. (1963). Blood group studies on the family of an $\mathrm{XX} / \mathrm{XY}$ hermaphrodite with generalized tissue mosaicism. American fournal of Human Genetics, 15, 62-68.

Grouchy, J. de, Moullec, J., Salmon, Ch., Josso, N., Frézal, J., and Lamy, M. (1964). Hermaphrodisme avec caryotype $\mathrm{XX} / \mathrm{XY}$ étude génétique d'un cas. Annales de Génétique, 7, 25-30.

Harnden, D. G., and Brunton, S. (1965). The skin culture technique. In Human Chromosome Methodology, pp. 57-73. Ed. by J. J. Yunis. Academic Press, New York.

Hecht, F., Antonius, J. I., McGuire, P., and Hale, C. G. (1966) $\mathrm{XXY}$ cells in a predominantly XX human male: evidence for cell selection. Pediatrics, 38, 982-985.

Josso, N., Grouchy, J. de, Auvert, J., Nezelof, C., Jayle, M. F., Moullec, J., Frézal, J., de Casaubon, A., and Lamy, M. (1965). True hermaphroditism with $\mathrm{XX} / \mathrm{XY}$ mosaicism, probably due to double fertilization of the ovum. Fournal of Clinical Endocrinology and Metabolism, 25, 114-126.

Miller, O. J. (1964). The sex chromosome anomalies. American fournal of Obstetrics and Gynecology, 90, 1078-1139.

Mittwoch, U. (1967). Sex Chromosomes. Academic Press, New York.

Moorhead, P. S., Nowell, P. C., Mellman, W. J., Battips, D. M., and Hungerford, D. A. (1960). Chromosome preparations of leukocytes cultured from human peripheral blood. Experimental Cell Research, 20, 613-616.

Overzier, C. (1964). Ein XX/XY-Hermaphrodit mit einem 'intratubulären Ei' und einem Gonadablastom (Gonocytom III). Klinische Wochenschrift, 42, 1052-1060.

Porter, I. A., Brown, C. D., Gergosian, L. A., and Paul, B. A. (1969). Evidence of selection in mosaicism. Fournal of Medical Genetics, 6, 310-313.

Taylor, A. I. (1968). Cell selection in vivo in normal/G trisomic mosaics. Nature (London), 219, 1028-1030.

Turpin, R., and Lejeune, J. (1965). Les Chromosomes Humains. Gauthier-Villars, Paris.

Waxman, S. H., Gartler, S. M., and Kelley, V. C. (1962). Apparent masculinization of the female fetus diagnosed as true hermaphroditism by chromosomal studies. Fournal of Pediatrics, 60, 540544.

Yunis, J. J. (1965). Human chromosomes in disease. In Human Chromosome Methodology, pp. 187-242. Ed. by J. J. Yunis. Academic Press, New York.

Zuelzer, W. W., Beattie, K. M., and Reisman, L. E. (1964). Generalized unbalanced mosaicism attributable to dispermy and probable fertilization of a polar body. American fournal of Human Genetics, 16, 38-51. 